\title{
Powłoki intermetaliczne otrzymywane w procesie przetapiania i stopowania
}

\author{
Intermetallic coatings produced \\ in melting and alloying process
}

\section{Streszczenie}

Praca przedstawia dotychczasowe wyniki badań nad wytwarzaniem warstw intermetalicznych Fe-Al z fazami Ti$\mathrm{Al}$ (Fe-Ti) za pomocą metod spawalniczych obejmujących przetapianie plazmowe powłok Al oraz stopowanie $\mathrm{Al} \mathrm{i} \mathrm{Ti}$ w procesie przetapiania podłoża metodą TiG AC. Przedstawiono badania mikrostruktury, analizy fazowej, mikrotwardości oraz naprężeń własnych.

Słowa kluczowe: powłoki intermetaliczne Fe-Al, przetapianie TIG AC, napawanie

\section{Abstract}

The paper presents current research results on producing Fe-Al intermetallic layers with Ti-Al (Fe-Ti) phases by welding methods. The plasma remelting of Al coating and alloying of $\mathrm{Al}$ and $\mathrm{Ti}$ in the process of surface remelting by AC TIG method were used. The microstructure, phase analysis, microhardness and residual stress analysis have been performed.

Keywords: Fe-Al intermetallic layers, AC TIG remelting, hardfacing

\section{Wstęp}

Badania nad materiałami intermetalicznymi prowadzone są w wielu ośrodkach naukowych na świecie. Obecnie najczęściej stosowanymi materiałami na bazie faz międzymetalicznych są materiały z układów: Fe-Al, Ti-Al oraz Ni-Al. Jednym z najbardziej obiecujących materiałów ostatnich lat ze względu na koszt materiałów podstawowych są stopy z grupy Fe-Al, z kolei ze względu na właściwości mechaniczne - stopy z grupy Ti-Al.

Materiały na bazie uporządkowanych faz międzymetalicznych z układów Fe-Al oraz Ti-Al charakteryzują się wysoką wytrzymałością i odpornością na utlenianie, a także małą gęstością. Mogą pracować w temperaturze powyżej $900{ }^{\circ} \mathrm{C}$ utrzymując przy tym stabilność struktury i wiązań chemicznych. Między innymi dlatego znajdują obecnie szerokie zastosowanie w przemyśle energetycznym, motoryzacyjnym, lotniczym, a także spożywczym [1-2].

W pracy zaproponowano nowe metody wytwarzania warstw intermetalicznych na podłożu stalowym. Procesy technologiczne zostały przeprowadzone za pomocą tradycyjnych metod z zakresu spajania. Pierwsza z metod opiera się na dwuetapowym procesie - łukowym natryskiwaniu czystego aluminium na podłoże stalowe, a następnie przetopieniu uzyskanej powłoki wraz z częścią materiału z podłoża. Obecnie, wytwarzane warstwy intermetaliczne poprzez natrysk cieplny gotowymi (komercyjnymi) proszkami na bazie faz międzymetalicznych są bardzo kosztowne. Dodatkowo warstwy takie wykazują skłonność do rozwarstwiania się, charakteryzują się wysoką porowatością oraz ograniczoną przyczepnością do podłoża. Natomiast proces przetapiania pozwala na uzyskanie drobnoziarnistej struktury materiału podstawowego. Dzięki takiej obróbce zlikwidowane zostają defekty struktury po obróbce plastycznej, a materiał podstawowy uzyskuje wysoką jednorodność i odporność na zmęczenie [3]. Połączenie tych dwóch procesów (natryskiwania oraz przetapiania) pozawala na uzyskanie warstwy na bazie faz międzymetalicznych oraz właściwości charakteryzujących warstwy przetapiane [4].

Kolejną zastosowaną metodą wytwarzania warstw intermetalicznych jest proces napawania. W kąpieli metalicznej bierze udział żelazo (ze stalowego podłoża) oraz materiały dodatkowe - aluminium oraz tytan. Obecnie, wytwarzanie warstw intermetalicznych wolnych od wad spawalniczych za pomocą napawania aluminium na stal jest praktycznie niemożliwe ze względu na to, że tworząca się warstwa pęka i złuszcza się. Dodatek tytanu w procesie napawania, ma na celu zmianę struktury wytwarzanej warstwy, która pozwoli uzyskać ciągłą warstwę intermetaliczną o wysokiej adhezji do podłoża. Ponadto, tytan podawany w procesie napawania do jeziorka spawalniczego, w którym zachodzi synteza aluminium z żelazem z podłoża, może dyfundować również do aluminium tworząc fazę międzymetaliczną z grupy Ti-Al. Powstała faza Ti-Al rozproszona w warstwie Fe-Al może korzystnie wpływać na jej właściwości. Wprowadzenie nowej fazy może mieć także korzystny wpływ na powstające w układzie warstwa-podłoże naprężenia własne [5-6].

mgr inż. Grzegorz Gontarz; dr hab. inż. Dariusz Golański, prof. PW; dr hab. inż. Tomasz Chmielewski, prof PW - Politechnika Warszawska.

Autor korespondencyjny/Corresponding author: ggontarz@wip.pw.edu.pl 
W badaniach nad wytwarzaniem warstw międzymetalicznych na podłożu stalowym zastosowano cztery metody oraz dwie techniki spawalnicze z wykorzystaniem urządzenia TIG AC oraz urządzenia plazmowego.

\section{Wytwarzanie warstw Fe-Al „Z warstwą pośrednią"}

Warstwę wytworzono w dwuetapowym procesie natryskiwania i przetapiania -metodami: TIG AC oraz łukiem plazmowym. W pierwszym etapie, na podłoże stali niestopowej (wag. 98,5\% Fe) w kształcie płytki o wymiarach 30 x 20 mm i grubości $2 \mathrm{~mm}$, natryskana została metodą łukową powłoka aluminium o grubości około 0,2 $\mathrm{mm}$.

W drugim etapie natryskana powłoka $z$ aluminium została przetopiona wraz z częścią stalowego podłoża (na całkowitej głębokości do ok. 0,5 mm) metodą TIG AC oraz łukiem mikroplazmowym. Dla metody TIG AC przetapianie prowadzono przy zastosowaniu prądu przemiennego o parametrach: natężenie prądu $65 \mathrm{~A}$, osłona gazowa - argon (11 l/min), odległość dyszy od przetapianej warstwy - $4 \mathrm{~mm}$, prędkość przesuwu palnika - $120 \mathrm{~mm} / \mathrm{min}$. Z kolei dla łuku plazmowego parametry przetapiania kształtowały się następująco: łuk pulsacyjny, maksymalne natężenie prądu $25 \mathrm{~A}$, napięcie łuku $11,7 \mathrm{~V}$, osłona gazowa - argon podawany z natężeniem przepływu $12 \mathrm{l} / \mathrm{min}$, gaz plazmowy - argon (natężeniem przepływu 0,6 I/min), odległość dyszy od przetapianej warstwy - $3 \mathrm{~mm}$, prędkość przesuwu palnika - $15 \mathrm{~mm} / \mathrm{min}$. Podczas przetapiania temperatura podłoża nie przekraczała $250{ }^{\circ} \mathrm{C}$.
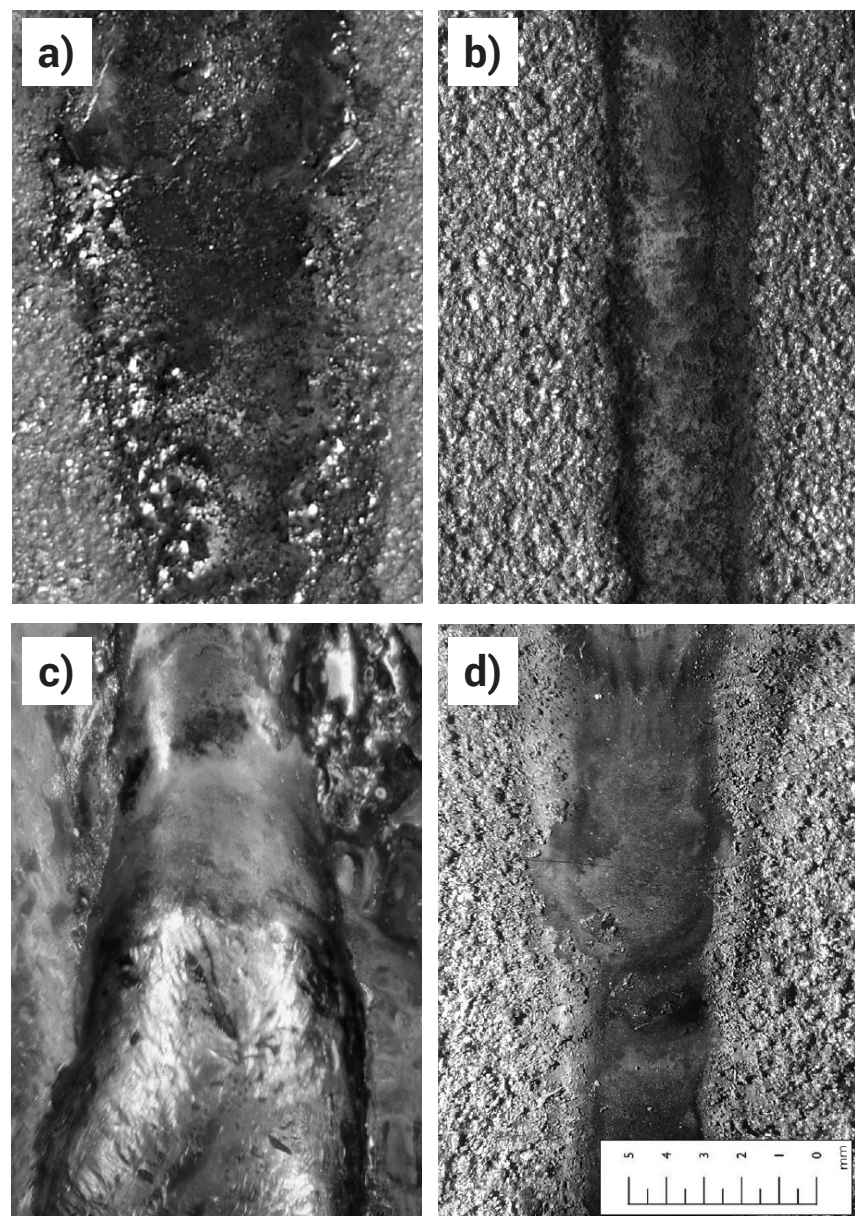

Rys. 1. Zestawienie zewnętrznych powierzchni po przetapianiu (a) TIG AC, (b) łukiem mikroplazmowym oraz napawaniu (c) TIG AC, (d) tukiem plazmowym

Fig. 1. Picture of sample surface after. (a) remelting by AC TIG, (b) remelting by microplasma arc, (d) hardfacing by AC TIG, (d) hardfacing by plasma arc

\section{Wytwarzanie warstw Fe-Al z fazami Ti-Al}

Warstwę wytworzono również z zastosowaniem dwóch metod: w jednoetapowym procesie napawania TIG AC oraz w dwuetapowym procesie: natryskiwania łukowego i napawania plazmowego. Warstwy wytworzono na stalowym podłożu (wag. 98,5\% Fe) w kształcie płytki o wymiarach $30 \times 20 \mathrm{~mm}$ i grubości $2 \mathrm{~mm}$.

W pierwszym przypadku napawano metodą TIG z użyciem prądu przemiennego aluminium oraz tytan $\mathrm{w}$ proporcjach 3:1. Do ciekłego jeziorka spawalniczego wprowadzano na przemian drut aluminiowy $(99,7 \%$ Al) o średnicy $2,4 \mathrm{~mm}$ oraz drut tytanowy $(99,9 \% \mathrm{Ti})$ o średnicy $0,8 \mathrm{~mm}$. Doświadczenie wykonano przy parametrach: natężenie prądu 80 A, osłona gazowa - argon (11 l/min), odległość dyszy od przetapianej warstwy $-3 \mathrm{~mm}$, prędkość przesuwu palni$\mathrm{ka}-150 \mathrm{~mm} / \mathrm{min}$.

W drugiej metodzie, na uprzednio natryskaną powłokę aluminiową napawano mikroplazmowo tytan (drut tytanowy 99,9\% Ti o średnicy 0,8 mm), tak aby przetopić zarówno powłokę jak i część stalowego podłoża. Zastosowano następujące parametry: natężenie prądu $30 \mathrm{~A}$, napięcie łuku 12,2 $\mathrm{V}$, osłona gazowa - argon podawany z natężeniem przepływu $12 \mathrm{l} / \mathrm{min}$, gaz plazmowy - argon (natężeniem przepływu $0,6 \mathrm{l} / \mathrm{min}$ ), odległość dyszy od przetapianej warstwy $-3 \mathrm{~mm}$, prędkość przesuwu palnika - $30 \mathrm{~mm} / \mathrm{min}$. Proces ten przedstawiono schematycznie na rysunku $2 \mathrm{~b}$.

Na rysunku 1 przedstawiono zestawienie makrostruktury powierzchni po przetapianiu oraz napawaniu wszystkimi metodami. Szerokość ściegu wynosiła od $3 \mathrm{~mm}$ dla przetapiania mikroplazmowego do ok. $5 \mathrm{~mm}$ dla TIG AC. Aby uzyskać większą powierzchnię tak wytworzonego stopu należy wykonać kilka ściegów zachodzących wzajemnie na siebie na szerokość ok. 20\% szerokości ściegu.

\section{Badania mikrostruktury}

W celu scharakteryzowania mikrostruktury wykonano podstawowe badania metalograficzne. Zestawienie obrazów mikrostruktury na granicy podłoże-warstwa pokazano na rysunku 2. Warstwa wytworzona poprzez przetapianie powłoki Al na stali (rys. 2a) jest wolna od pęknięć i porowatości charakteryzujących warstwy natryskiwane. Zapewnia to wysoki poziom szczelności i brak karbów o charakterze geometrycznym, koncentrujących naprężenia. Ewentualna porowatość może występować jedynie w wierzchniej części warstwy. Największą zaletą przeprowadzonego procesu w stosunku do powłok intermetalicznych natryskiwanych bezpośrednio jest metalurgiczne związanie warstwy z podłożem. Otrzymana warstwa jest jednorodna i ciągła.

Po przetapianiu mikroplazmowym (rys. 2b) w obszarze nowopowstałego stopu obserwujemy charakterystyczną dla faz międzymetalicznych komórkową budowę mikrostrukturalną o średnim rozmiarze ziaren na poziomie $20 \mu \mathrm{m}$ oraz dyspersyjne wydzielenia innych związków o wymiarach nieprzekraczających $2 \mu \mathrm{m}$. Analizowana warstwa jest wolna od pęknięć i porowatości charakteryzujących warstwy natryskiwane.

Warstwa wytworzona poprzez napawanie aluminium oraz tytanu na podłożu stalowym (rys. 2c) również nie posiada pęknięć oraz porowatości. W obszarze nowopowstałego stopu można zauważyć wydzielenia innych faz (prawdopodobnie z układu Ti-Al). Obecność równomiernie rozproszonych w objętości obszaru napoiny cząstek innych faz może mieć pozytywny wpływ m.in. na właściwości mechaniczne wytworzonej warstwy. W strefie wpływu ciepła obserwuje się znaczny rozrost ziaren. 
Ostatnia prezentowana warstwa, powstała w wyniku oddziaływania łuku plazmowego na powłokę Al charakteryzuje się dobrze widoczną komórkową budową o średnim rozmiarze ziaren na poziomie $30 \mu \mathrm{m}$. Zauważalne są również wydzielenia innych faz równomiernie rozmieszczone w strukturze wytworzonego materiału. Podczas procesu napawania została przetopiona aluminiowa powłoka wraz z częścią stalowego podłoża.
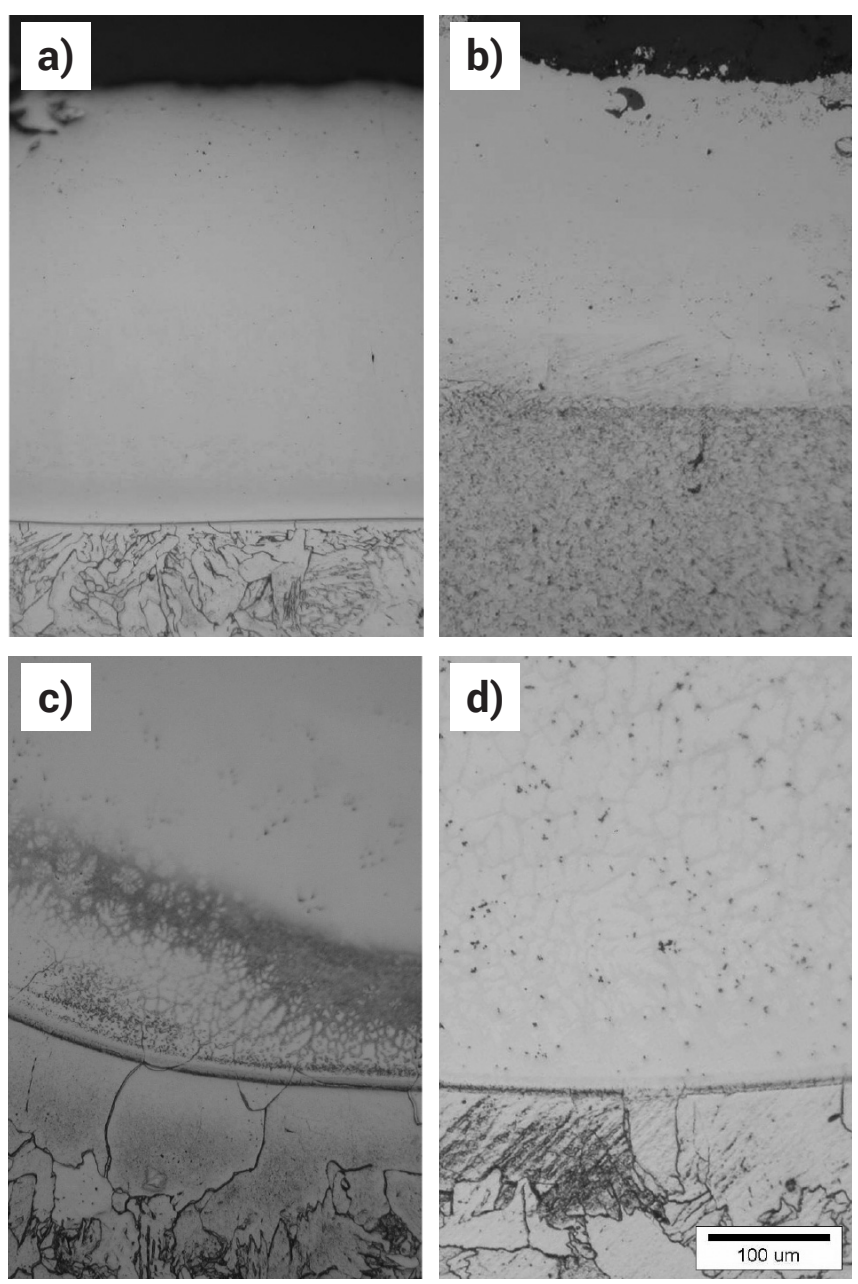

Rys. 2. Mikrostruktura warstwy (a) po przetopieniu Al metodą TIG AC, (b) po przetopieniu Al łukiem mikroplazmowym (c) po napawaniu Al z dodatkiem Ti metodą TIG AC, (d) po napawaniu Ti na Fe z międzywarstwą Al łukiem plazmowym

Fig. 2. Microstructure of the layer (a) after Al remelting by AC TIG, (b) after Al remelting by microplasma arc, (c) after harfacing by AC TIG of Al with Ti addition, (d) after plasma arc harfacing of $\mathrm{Ti}$ on $\mathrm{Fe}$ with Al interlayer

W celu scharakteryzowania struktury przeprowadzono rentgenowską analizę fazową wytworzonych warstw. $\mathrm{Na}$ rysunku 3a pokazano dyfraktogram powstałej warstwy po procesie przetapiania aluminium na podłożu stalowym metodą TIG AC. Wyniki rentgenowskiej analizy fazowej potwierdzają obecność fazy FeAl wtórnego roztworu stałego, a jednocześnie potwierdzają udział innej fazy $\mathrm{Fe}_{2} \mathrm{Al}_{5}$ jako głównego składnika strukturalnego. Wyniki rentgenowskiej analizy fazowej warstwy wytworzonej poprzez przetapianie mikroplazmowe powłoki Al (rys. 3b) potwierdzają obecność fazy FeAl jako głównego składnika strukturalnego, dodatkowo wykazują nieznaczny udział innych faz ubocznych, takich jak $\mathrm{Fe}_{2} \mathrm{O}_{3}$ oraz $\mathrm{Fe}_{2} \mathrm{Al}_{5}$. Faza $\mathrm{Fe}_{2} \mathrm{O}_{3}$ powstała podczas przetapiania warstwy natryskanej z podłożem na skutek reakcji żelaza z tlenem atmosferycznym. We wcześniejszym etapie tj. po natryskaniu nie zarejestrowano jej obecności w warstwie. a)
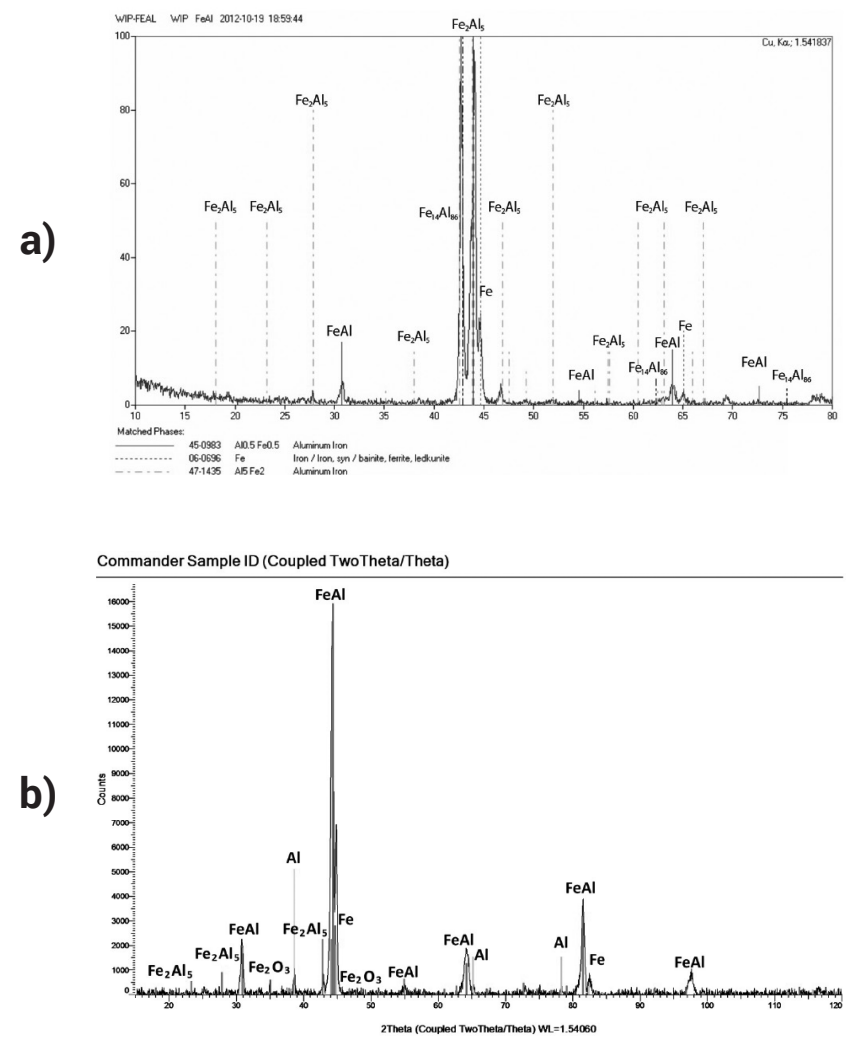

c)
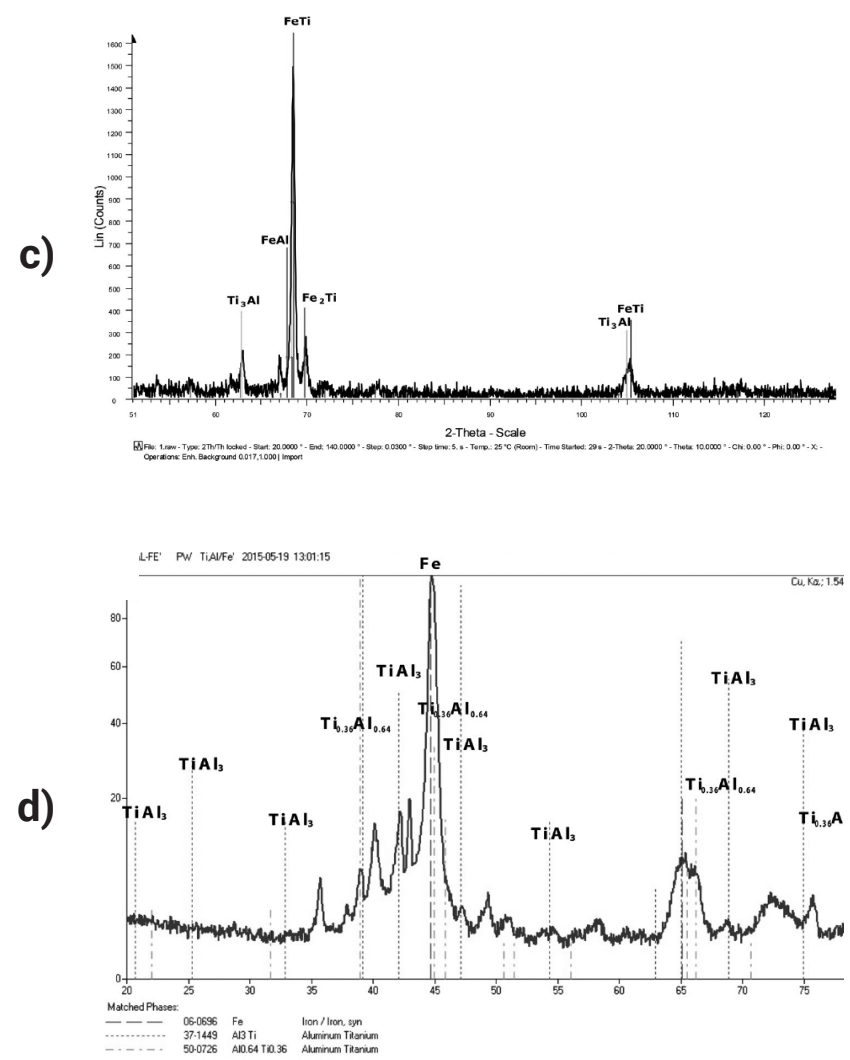

Rys. 3. Dyfraktogram przetopionej powłoki Al metodą TIG AC

Fig. 3. Diffraction patterns of remelted Al coating by AC TIG

Badania dyfrakcji rentgenowskiej próbki z warstwą Al + Ti napawaną na podłoże stalowe (rys. 3c) wykazały, że pomimo głębokiego wtopienia w podłoże i wymieszania składników, uzyskano fazę $\mathrm{Fe}_{2} \mathrm{Ti}$ jako główny składnik strukturalny. Dodatkowo uzyskano także wydzielenia fazy FeAl oraz fazy TiAl.

Dyfraktogram warstwy powstałej w wyniku napawania Ti na podłoże stalowe z międzywarstwą Al (rys. 3d) wykazuje jedynie obecność fazy TiAl3 oraz obecność żelaza - niepowiązanego z pozostałymi składnikami warstwy. 


\section{Badania mikrotwardości}

Przeprowadzono badania mikrotwardości w stalowym podłożu oraz wytworzonej warstwie dla wszystkich zastosowanych metod (rys. 4). Twardość badano na całym przekroju próbki w celu ujawnienia ewentualnego oddziaływania cyklu cieplnego również na podłoże. W podłożu odnotowano wzrost twardości do poziomu około $350 \mu \mathrm{HV} 0,1$ jedynie w obszarze strefy wpływu ciepła (SWC), która swoim zasięgiem obejmowała pasmo o szerokości około $0,25 \mathrm{~mm}$ dla metody przetapiania powłoki aluminiowej metodą TIG AC oraz 0,4 - 0,6 mm dla metody napawania aluminium oraz tytanu. Dla przetapiania mikroplazmowego odnotowano nieznaczny wzrost twardości w SWC, natomiast dla napawania plazmowego odnotowano wzrost twardości również w stalowym podłożu.

W warstwie właściwej zarejestrowano twardość w zakresie wartości 890-1020 $\mu \mathrm{HV} 0,1$ dla przetapiania prądem przemiennym metodą TIG oraz 450-570 $\mu \mathrm{HV} 0,1$ dla napawania Al i Ti na stali, 520-810 $\mu \mathrm{HV} 0,1$ dla przetapiania mikroplazmowego oraz 650-1100 $\mu \mathrm{HV} 0,1$ dla warstwy wytworzonej poprzez napawanie plazmowe. Dla wszystkich zastosowanych metod, zmierzone wyniki mikrotwardości warstwy mieszczą się we właściwym zakresie dla faz międzymetalicznych z układów Fe-Al oraz Ti-Al, a ich wartości są prawdopodobnie zależne od ilości wydzielonych innych faz. Otrzymane wyniki odzwierciedlają jednorodność chemiczną i strukturalną wytworzonych warstw.

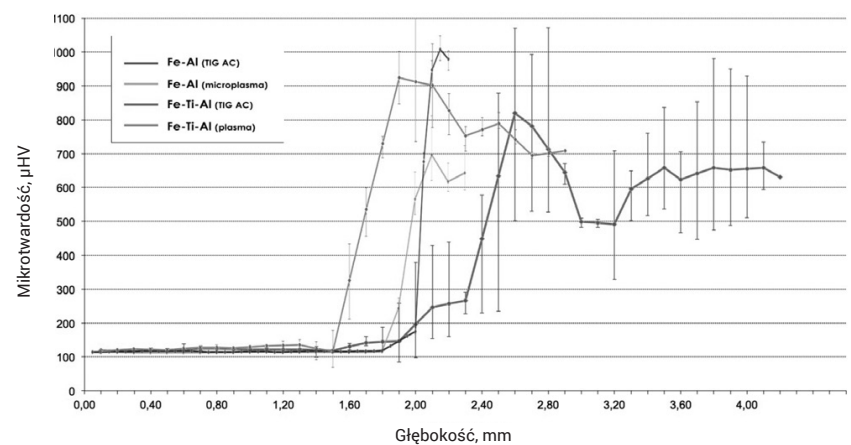

Rys. 4. Rozkład twardości na przekroju próbki: w stalowym podłożu i wytworzonej warstwie

Fig. 4. Microhardness distribution across the sample depth: in steel substrate and in produced layer

Badania mikrotwardości przeprowadzono również na „powierzchni użytkowej” wytworzonej warstwy. Płaszczyznę tą otrzymano poprzez zeszlifowanie na głębokość $10 \%$ wytworzonej warstwy. Jednolita powierzchnia została zbadana w przestrzeni $0,4 \times 0,45 \mathrm{~mm}$. Powierzchnia po przetapianiu warstwy aluminiowej metodą TIG AC charakteryzuje się równomierną twardością w całym obszarze pomiarowym i mieści się w zakresie 900-1000 $\mu \mathrm{HV}_{0,1}$. Rozkład twardości dla powierzchni po przetapianiu łukiem mikroplazmowym obejmuje wąski przedział wartości w zakresie 570$-610 \mu \mathrm{HV}_{0,1}$. Powierzchnia po napawaniualuminium oraz tytanu wykazuje duże skoki twardości (500-1000 $\left.\mu \mathrm{HV}_{0,1}\right)$. Ostatnia warstwa, wytworzona poprzez napawanie tytanu na stal z międzywarstwą aluminiową, charakteryzuje się stabilną twardością na poziomie $770-880 \mu \mathrm{HV}_{0,1}$.

\section{Badania naprężeń własnych}

Przeprowadzono badania naprężeń własnych w wytworzonych warstwach oraz w podłożu z wykorzystaniem pomiarów krzywizny wygięcia próbek. Na specjalnie zbudowanym stanowisku pomiarowym zmierzono wartości ugięcia próbek po wytworzeniu warstwy i na podstawie zmodyfikowanych równań Stoney'a wyznaczono naprężenia układzie warstwa-podłoże.

Naprężenie średnie w powłoce/warstwie można wyznaczyć według podstawowego równania Stoney'a, które zakłada, że grubość warstwy jest dużo mniejsza od grubości podłoża. Jeśli warunek ten nie jest spełniony tzn. grubość warstwy nie jest dużo mniejsza od grubości podłoża to można w tym celu odpowiednio zmodyfikować równanie Stoney'a uzyskując wartości naprężeń w warstwie i podłożu. Zależności te opisał w sposób analityczny Clyne [7] otrzymując rozwiązanie umożliwiające wyznaczenie naprężeń na kierunku x w warstwie i podłożu. Uwzględniając te zależności dla wytworzonych warstw na żelazie (Fe) otrzymujemy następujący wykres zmiany naprężenia $\sigma_{\mathrm{x}}$ (rys. 5) na przekroju warstwapodłoże.

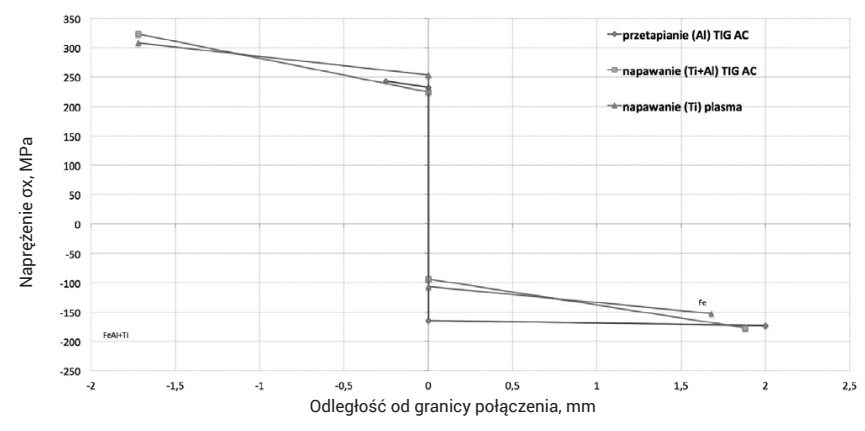

Rys. 5. Rozkład twardości na przekroju próbki: w stalowym podłożu i wytworzonej warstwie

Fig. 5. Microhardness distribution across the sample depth: in steel substrate and in produced layer

W warstwie występują rozciągające naprężenia własne o wartościach do ok. $250 \mathrm{MPa}$ dla warstw powstałych przez przetapianie aluminium metodą TIG AC oraz do 300-320 MPa dla warstw otrzymanych przez napawanie odpowiednio z udziałem Ti oraz Ti+Al. Największe naprężenia występują w warstwie wytworzonej poprzez napawanie plazmowe tytanu na podłoże stalowe z międzywarstwą Al. Charakterystyczne w takich układach jest występowanie gwałtownego skoku naprężenia na granicy warstwy i podłoża. Naprężenia własne w stalowym podłożu mają charakter ściskający i kształtują się na poziomie od -100 MPa do ok. -160 MPa.

\section{Wnioski}

Wykorzystanie tanich i ogólnodostępnych materiałów wyjściowych (niezawierających drogich pierwiastków stopowych np. takich jak nikiel czy chrom), kilkakrotnie zmniejszy koszt wytwarzania tego typu warstw intermetalicznych. Może to stanowić alternatywę dla obecnie stosowanych metod modyfikacji powierzchni stalowych, opartych na pokrywaniu ich drogimi komercyjnymi fazami międzymetalicznymi (najczęściej w formie proszku).

Zastosowanie proponowanej nowej metody wytwarzania warstw ze stopu bazującego na uporządkowanych fazach 
międzymetalicznych z układu Fe-Al oraz Ti-Al do regeneracji zużytych części maszyn oraz na powierzchnie narzędzi, może wpłynąć na aspekt ekonomiczny i przyczynić się do zastąpienia tą metodą innych, mniej efektywnych metod produkcji. Dodatkowo, opracowanie nowej metody wytwarzania warstwy intermetalicznej typu Fe-Al z dodatkiem tytanu jako warstwy przejściowej, może przyczynić się do rozwiązania problemu łączenia konstrukcji stalowych z elementami aluminiowymi.

Wykorzystanie w procesie przetapiania skoncentrowanej energii cieplnej prowadzi do powstania uporządkowanej, komórkowej budowy struktury, charakterystycznej dla materiałów intermetalicznych. Wytworzone warstwy wykazują niewielki rozrzut twardości na całej powierzchni materiału.

Wytworzone warstwy bazujące na związku typu Fe-Al, Fe-Ti oraz Ti-Al mogą w przyszłości znaleźć zastosowanie jako warstwy pośrednie do połączeń konstrukcji stalowych z elementami aluminiowymi. W przemyśle nie stosuje się jeszcze metod spawalniczych do wytwarzania połączeń stal-aluminium.

Przeprowadzone badania właściwości otrzymanych warstw wskazują ich ciągłą oraz jednorodną budową. Zmierzona podwyższona mikrotwardość warstw pokazuje i potwierdza występowanie faz międzymetalicznych w warstwach, które zidentyfikowane zostały poprzez rentgenowską analizę fazową. Badania naprężeń własnych pokazały, że naprężenia rozciągające w badanych warstwach osiągają maksymalne wartości od 230 do 320 MPa w zależności od zastosowane metody ich wytwarzania. Wielkość powstających naprężeń zależy także od grubości warstwy (rośnie ze wzrostem grubości) i jest tym wyższa im większe jest oddziaływanie wysokiej temperatury na podłoże.

Podziękowania: Praca finansowana ze środków na prace dziekańską nr 504M/1104/0591/000 w roku 2014 na Wydziale Inżynierii Produkcji.

\section{Literatura}

[1] J.C. Wiliama: Intermetallics for structural applications: potential, reality and road ahead, Structural Intermetallics, ed. M.V. Nathal et. al., TMS 1997, pp. 3-8.

[2] J. Bystrzycki, R.A. Varin, Z. Bojar. Postępy w badaniach stopów na bazie uporządkowanych faz międzymetalicznych z udziałem aluminium, Inżynieria Materiałowa 1996, 5, s. 137-149.

[3] G. Gontarz: Przetapianie warstw powierzchniowych nanoszonych metodami spawalniczymi, Zeszyt Naukowy Mechanika, nr 230: Spajanie we współczesnej technice, Oficyna wydawnicza PW, Warszawa 2010 s. 115-129.

[4] G. Gontarz, T. Chmielewski, D. Golański: Modyfikacja natryskiwanych powłok aluminiowych na stali skoncentrowanym źródłem ciepła, Przegląd Spawalnictwa, $\mathrm{Nr}$ 12/2011, s. 52-54.

[5] G. Gontarz, D. Golański, T. Chmielewski: Properties od Fe-Al type intermetallic layers produced by AC TIG method, Advances in Materials Science, Vol.13, No.3 (37) 2013, pp. 5-16

[6] D.Golański, T.Chmielewski, G.Gontarz, J. Zimmerman, W. Włosiński.: Badania naprężeń własnych $w$ powłokach natryskiwanych metodą HVOF, Przegląd Spawalnictwa, 10 (2013), s. 30-36.

[7] T.W. Clyne, S.C.Gill: Residual Stresses in Surface Coatings and Their Effects on Interfacial Debonding: A Review of Recent Work, J. Thermal Spray Technology, (1996), Vol. 5(4), pp. 401-418. 